\title{
Austerity or Xenophobia? The Causes and Costs of the "Hostile Environment" in the NHS
}

\author{
Arianne Shahvisi ${ }^{1}$ (D) \\ Published online: 3 June 2019 \\ (c) The Author(s) 2019
}

\begin{abstract}
During the "age of austerity" the UK government has progressively limited free health services for "overseas visitors" on the grounds of fairness and frugality. This is despite the fact that the cost of the additional bureaucracy required by the new system and the public health consequences are expected to exceed the sums saved. In this article I explore the interaction between the discourses of austerity and xenophobia as they relate to migrants' access to healthcare. By examining the available data and adjudicating various moral arguments, I cast doubt on the claim that the current charging regulations are cost-effective and fair. I instead contend that if the UK is concerned with running a health service that is economically-sustainable and morally-defensible, it is critical that migrants are welcomed, both as staff and as patients. I conclude by arguing that xenophobia has precipitated changes to the health service which do not qualify as "austerity" in the way that is claimed, but rather deliberately produce a "hostile environment" for migrants, despite this very likely generating economic losses.
\end{abstract}

Keywords Austerity $\cdot$ NHS $\cdot$ Migrants $\cdot$ Cosmopolitanism $\cdot$ Racism $\cdot$ Xenophobia

\section{Introduction}

In recent years, the UK government has restricted migrants' access to the National Health Service (NHS), reducing the services which are free, and charging for others. It has claimed to have done so for reasons of fairness and frugality, in concert with other welfare cuts as part of a programme of austerity over the last decade.

In this article I contend that while changes to migrants' access to the NHS are presented as an austerity measure, they are in fact more likely to be responsive to a political climate of rising xenophobia, with austerity acting as a smokescreen for a more determinative anti-immigration discourse. By examining the available

Arianne Shahvisi

a.shahvisi@bsms.ac.uk

1 Brighton and Sussex Medical School, Biology Road, Falmer, Brighton BN1 9PX, UK 
data and adjudicating various moral arguments, I cast doubt on the claim that the current charging regulations are cost-effective and fair, and instead show that the government has deliberately and pragmatically produced a "hostile environment" for migrants, despite this very likely generating economic losses. I argue that it is critical to the future of the NHS that migrants are welcomed, both as staff and as patients.

This paper is structured as follows. In the first section, I describe recent changes to NHS care for migrants, which have been introduced as part of a broader programme of "austerity." In the second section, I show that fairness and frugality are the government's stated objectives in charging migrants. The following sections examine some of the data around the costs and savings of the new regime to determine whether or not it is likely to be cost-effective, and then adjudicate a series of moral arguments that might be used to ground the charging of migrants, in order to determine whether or not the new system can be argued to be fair. I then propose moral arguments for extending free NHS care to all migrants and conclude by arguing that xenophobia has been more determinative of the current charging regime than austerity.

This paper provides a novel perspective on the confluence of austerity discourse and xenophobia as they jointly contribute to the new restrictions around migrants' access to the NHS. In addition, by evaluating a range of philosophical arguments for and against migrants' inclusion as full "citizens" of the NHS, it contributes to the debate around migrants' entitlements to welfare services more generally.

\section{The Hostile Environment in the NHS}

The global financial crisis of 2008 triggered the "Great Recession," to which the UK government responded by heralding an "age of austerity" and implementing a deficit reduction programme [15]. Austerity is a fiscal strategy characterised by a reduction in the ratio of tax spending to tax revenue, achieved either by decreasing the former or raising the latter. Austerity measures in the UK have primarily focussed on reducing public spending rather than increasing tax income.

The UK government assured the public that austerity measures would not affect the NHS, a popular institution upon which most UK residents are reliant [76]. It was claimed that NHS funding would be ring-fenced while the deficit would be closed by making cuts to government spending elsewhere. This promise was not honoured, and funding to the NHS as a proportion of national spending has fallen over the last decade $[42,57]$. The NHS budget is currently growing by just $3 \%$ each year, compared with an average $4.1 \%$ growth rate since the 1950s [43]. Further, other welfare cuts and reforms have drastically affected the social determinants of health in ways that have increased the burden on the NHS, by e.g. exacerbating poverty, homelessness, and unemployment $[5,65]$. Over the same period, the NHS has been spending two to three billion pounds each year in hiring agency staff to address a rising number of vacancies, a situation which has been exacerbated by the effects of austerity on recruitment and retention [77]. 
In at least one domain, the government has been candid and even forthright about its commitment to cutting NHS services. In an interview with The Telegraph in 2012, then-home secretary Theresa May stated that in removing public services for migrants, "the aim is to create here in Britain a really hostile environment for illegal migration" [41]. Accordingly, a year later, her infamous "Go Home" billboard buses under "Operation Vaken" patrolled six London boroughs with sizeable immigrant populations, threatening undocumented migrants with arrest or "voluntary deportation" [75]. Soon afterwards, the Immigration Act 2014 came into force, one of whose aims was "to limit [...] access to services, facilities and employment by reference to immigration status" [35]. Amongst other changes, the Act restricted free NHS coverage to those who are "ordinarily resident," requiring all those who could not prove they had been resident in the UK for five years to pay for their care. In 2017, up-front charges were introduced with the aim of improving cost recovery, requiring chargeable NHS patients to pay for their care before receiving it [77]. Over the course of just a few years, access to the NHS for migrants has been drastically reduced, and the range of different entitlement categories has multiplied [64].

Some NHS services remain freely available to all: primary care; care given immediately within an accident and emergency department; treatment for certain communicable diseases (e.g. HIV, TB, and STIs); palliative care; contraceptives; and care which attends to the physical and mental effects of violence [65]. ${ }^{1}$ Beyond this basic care, the NHS is a four-tier system, which operates as follows:

(i) Those who are ordinarily resident, refugees, or asylum-seekers, do not pay for their care;

(ii) Visa-holders pay the "Immigration Health Surcharge" of $£ 400$ per year and may thereafter access NHS care without additional charge;

(iii) Patients from states within the European Economic Area (EEA) pay an upfront charge equalling the face-value cost of treatment; ${ }^{2}$

(iv) Those from outside the EEA, including those yet to apply for asylum, those whose asylum-applications have been refused, those who have over-stayed their visas, and all undocumented migrants, pay an up-front charge equalling $150 \%$ of the face-value cost of treatment [20].

As these changes have been enforced by the Department of Health and Social Care, the NHS has found itself increasingly entangled with the Home Office, as part of the broader "hostile environment" strategy. Between January 2017 and May 2018, a memorandum of understanding required healthcare workers to share the names and addresses of undocumented migrants with the Home Office [36, 1]. While at the time of writing that memorandum has been suspended, if a non-EEA patient has a debt of $£ 500$ or greater within 2 months of receiving care, their data must be shared with the Home Office, where it may be used in the assessment of any current or

\footnotetext{
1 Notably, pregnancy care, including abortion, is not included in the set of free services [67].

2 If the patient has a valid European Health Insurance Card, some services beyond the aforementioned basic care are also free [78].
} 
future applications for the right to remain in the UK [20]. It is also important to note that undocumented migrants [who fall into category (iv)], are often destitute and are forbidden from working in any formal sector [60].

These changes were introduced in 2014 in the midst of wider austerity measures, and, as I will show in the next section, are justified primarily in economic terms. They may therefore be categorised as part of the broader programme of austerity.

\section{The Motivation for Austerity in Migrant Healthcare: Fairness and Frugality}

The aim of this section is to show that fairness and frugality are the government's stated objectives in charging migrants for NHS care. These motivations can be inferred from policy documents and parliamentary debates from 2012 to the present.

In the previous section, austerity was defined as a set of measures intended to reduce the public-spend/public-revenue ratio. While the global financial crisis has been cited as the general motivation for austerity measures, the particular funding cuts that are made are typically justified in normative terms. These restrictive measures are presented as an economic necessity which, in a time of scarcity, reinstates fairness. Indeed, the welfare reforms undertaken under the austerity regime were described by the prime minister as a "moral mission" [63]. As a rule, all UK austerity measures have been legitimated in this way, which seems to align with the values of the UK public [73].

The incentive for charging migrants for their care has always been articulated primarily in economic terms. The Department of Health and Social Care states that:

At a time of increased financial challenge for the NHS, every organisation needs to ensure they are meeting their legal obligation and maximising the cost recovery potential [20].

In the foreword to a 2013 government report, entitled "Controlling ImmigrationRegulating Migrant Access to Health Services in the UK," Theresa May stated that "the current rules regulating migrant access to the NHS are too generous, particularly when compared with wider international practice, poorly applied and act as a draw to health tourists" [48]. The report goes on to claim that "This level of generosity has been the subject of ongoing public concern" [48].

In a written statement in the House of Commons in 2013, the motivation for charging was described as follows:

[P] ublic services like the NHS are under increasing strain, coping with the demands of an ageing population and financial pressures. The NHS is and will remain free at the point of delivery for its residents, but it cannot continue as an international rather than a national health service. We urgently need to address this or the system is likely to become unsustainable [45].

In another government report, tellingly entitled "Making a fair contribution," it is claimed that charging migrants for their healthcare is "one way we can ensure the 
NHS is sustainable for us all in years to come" [18]. Later on, the concern about the NHS being "financially sustainable" is reiterated. In 2014, then-Secretary of State for Health Jeremy Hunt described the restrictions in similar terms:

The Department of Health is working to create a fairer NHS by improving the systems for charging overseas visitors and migrants to make sure they contribute towards their NHS health care. It is clear that more can be done to increase cost recovery [82].

Again, financial sustainability is a key stated driver of the new charging regime, with Hunt going on in the same debate to emphasise healthcare providers' "statutory obligation to support NHS sustainability through appropriate identification and charging of visitors and migrants."

Similarly, three years later then-Minister of State for Health Philip Dunne claimed that the changes:

aimed to support the principle of fairness by ensuring those not resident in the United Kingdom pay for NHS care. The proposals would not restrict access, but rather make sure that everyone makes a fair contribution towards the cost of the care they receive [50].

In relation to entitlement to a public service, fairness and frugality are obviously linked. Resources are finite, and generally scarce, particularly during times of austerity. Later in the article, I explore various notions of fairness, but regardless of one's definition, in order for a scarce resource to be allocated in a way that is fair, it presumably must be used as efficiently as possible, since waste and excess detract from the budget available for providing for the needs of service-users. Therefore, fairness in relation to public services requires considerations of frugality. And frugality in an already streamlined system generally means removing access to some services, which requires normative judgments to be made.

The justifiability of the new charging regime ${ }^{3}$ therefore depends on the veracity of two claims: that restricting migrants' access to the NHS (a) saves money, and (b) makes the service fairer. In the next two sections I examine whether these objectives are being met.

\section{Is It Cost Effective to Charge Migrants for Their Healthcare?}

In this section, I examine some of the data around the costs and savings of the new regime in order to identify any divergence between the government's claims and the operative reality, and thereby test the claim of cost-effectiveness.

At its highest estimate, the cost of deliberate health tourism is around $0.3 \%$ of the annual NHS budget, amounting to around 300 million pounds [34]. Moreover, the UK is a net-exporter of medical tourists, with more UK citizens seeking treatment

\footnotetext{
${ }^{3}$ It may be that welfare cuts are never justifiable, even in times of economic recession, but that takes us beyond the scope of this paper.
} 
abroad than health tourists to the UK [32]. Under the current charging regime, the government intends to recover 500 million pounds per year through charging for NHS services via up-front payments from "overseas visitors" and immigration health surcharges from visa-holders [17], but a National Audit Office report suggests that 346 million pounds per year is a more realistic aim [51]. Even at this lower estimate, available data casts doubt on the prospect of cost recovery outweighing the cost of administrating the new system. A 2017 pilot scheme found that of 8900 patients who were identified for upfront charging, only 50 patients were charged for their care [46], and in 2016, a hospital in Hampshire spent $£ 231,000$ funding an "overseas visitor management team" [24], yet recovered just $£ 50,000$ from chargeable patients [25]. It seems doubtful that the new up-front charging regime could produce the almost fivefold increase in cost recovery required to offset the bureaucratic costs. Further, the government has admitted that its assessment of cost recovery makes "broad assumptions" based on data that is "incomplete or inconsistent" [16] and that it does not have a firm sense of the number of people who are chargeable [85]. All this seems to dispute the idea that charging migrants is motivated by fiscal considerations. While one might argue that failures to accurately estimate the costs of charging migrants could point to government incompetence rather than any pernicious intention, there are moral questions to be asked about a government that introduces a policy which effectively removes healthcare from a vulnerable group without first ensuring that there will be greater overall benefits, and which then fails to overturn the policy when it becomes evident that the costing was not rigorous, and that considerable moral and financial costs are incurred elsewhere.

Half of all doctors joining the NHS workforce in 2018 were trained outside the UK [27], a figure which is not unusual in a health service that has always been dependent on its migrant workforce [70]. Yet the same "hostile environment" that restricts migrants' access to the NHS also affects the ability of the NHS to hire workers from abroad. In 2008, just as the global financial crisis was unfolding, the government announced the "points-based immigration system" whose aim was to reduce the number of immigrants to the UK. ${ }^{4}$ An immigration cap followed in 2010, limiting the number of non-EU migrants to 24,100 per year [69]. This has affected the ability of the NHS to reach safe staffing levels. In 2015, the NHS Employers Organisation estimated that around 1000 applications from non-EU nurses were refused due to caps on visas for non-EU workers [84], and in 2018, the General Medical Council (GMC) announced that at least 400 doctors were unable to take up positions in the UK [26]. Many others will have been deterred from applying due to visa restrictions.

An exemption to the cap was implemented for nurses and doctors in 2018 under pressure from medical professional bodies, but at the time of writing, the NHS has 103,000 vacancies [52]. Not only do these vacancies threaten the quality of NHS care, but the temporary agency staff employed to maintain safe staffing levels are considerably more expensive than salaried staff. Between 2014 and 2015, the NHS

\footnotetext{
4 That the point-based system was introduced in order to reduce immigration in response to public pressure may be witnessed within parliamentary debates on the matter, e.g. [62].
} 
spent more than three billion pounds on agency costs [53], which led to the introduction of caps on the pay of agency workers. Even so, it is estimated that the NHS spent 2.4 billion on agency nursing staff alone in 2018, equivalent to the cost of employing an additional 66,000 nurses, almost twice as many as are needed to fill existing vacancies [77]. It is important to note that the dearth of NHS nurses has been exacerbated by other health-related austerity measures which have affected recruitment and retention. More than half of nurses report negative effects on the profession following funding cuts, a quarter are unable to access training opportunities due to reduced training budgets, and two-fifths have been impacted by public sector pay caps. Following the removal of bursaries for student nurses in 2017, the number of applications for nursing degrees has fallen by a third [75].

Another factor to consider is the cost to the state of excluding or deterring migrants from using the NHS. Research undertaken in Germany shows that it is more costly to exclude migrants from healthcare services than to extend the full raft of services to all [7]. The confusion that has arisen in the UK around charging regulations and Home Office involvement means that many migrants avoid healthcare services altogether, even those to which they are entitled, or that they may wait until their medical problems progress into emergencies, leading to worse health outcomes and greater cost $[13,60]$. Emergency care is much more expensive than planned care, and the risk of dangerous and expensive disease outbreaks is also increased [38]. Further, the checks involved in establishing the eligibility for care can lead to delays in diagnosis and treatment which ultimately cost the service more. The government has not factored into their calculations the costs that are likely to be incurred as chargeable patients' use of accident and emergency services rises, either as untreated ailments escalate, or as people seek treatment in the areas of the NHS that remain free to all [85].

\section{Is It Fair to Charge Migrants for Their Healthcare?}

The government claims that charging those who are not ordinarily resident for their healthcare is fair, but the moral basis for that assertion is never spelled out. In this section, I outline and adjudicate the various notions of fairness that might be used to justify this claim.

Based on the documents cited earlier in this article, the government's notion of fairness is likely arbitrated according to the following principle: only those who contribute to the health service should be permitted to benefit from it. This is a principle that may seem especially urgent in times of austerity. The NHS is funded through general taxation, therefore a "fair" system might exclude all those who do not pay taxes, and include all those who do. Yet applying such a scheme consistently would mean that all visa-holding migrant workers would have free care, while many non-tax-payers who are ordinarily resident would not. As it stands, those who are ordinarily resident are afforded free care regardless of tax contributions, while those who are not must pay regardless of their tax contributions. Although those who are ordinarily resident are usually related to others who have paid taxes, and might accordingly be afforded access to the NHS, the same argument can be adapted 
to include migrants. Given that large numbers of health-workers from Global South nations have come to work within the NHS, having had their training funded in part by the taxpayers of their own states, and then having contributed to the NHS through taxation, by the same reasoning they and their relatives could surely claim some right to free access. ${ }^{5}$

Similarly, since taxpayers' earnings fund the NHS, fairness might be taken to require that those contributions be directed solely or largely towards the interests of taxpayers, i.e. towards their health and that of their dependents and relatives. Extending free healthcare to non-contributors may be seen as an unfair use of taxpayers' contributions, in that the cost (in both time and money) of non-contributors' care diverts resources away from taxpayers' healthcare. Yet as we have seen, the cost of charging non-contributors for their care exceeds the costs recovered.

Another way of adjudicating fairness might be to consider the net contribution of migrants to the UK economy as a whole. A strong economy enables a well-funded NHS. One might reason that provided migrants can be shown to have made a net contribution to the economy, including over periods in which they have been entitled to free NHS care, then it is only fair that they be permitted to use the NHS for free. A recent study shows that immigrants arriving in the UK between 2000 and 2011, a period during which most migrants would have been able to use the NHS without charge, made a positive contribution to the UK economy of around $£ 25$ billion. The cost recovery target of $£ 500$ million pales in contrast to this sum, and the figure is yet more striking when one considers that "native" residents made a negative contribution of $£ 617$ billion [21].

These first three notions of fairness have at their root the "free-rider" problem, according to which it is morally troubling for those who do not contribute to a service to benefit from the contributions of others [33]. However, it is not clear whether the free-rider problem applies to healthcare as easily as it might apply to other goods. Denying healthcare to some in order to prevent free-riding is self-defeating if it interferes with the ability of others to maintain good health. Consider that if some people were forbidden or deterred from receiving vaccinations, or treatments for infectious diseases, they and others may be put at risk. Further, it is misleading to refer to migrants as "free-riders" when current employment laws forbid them from working, or force them to work illegitimately in the non-taxable informal economy, thereby preventing them from contributing.

One might be concerned with fairness particularly in relation to undocumented migrants' access to the NHS. Their residence within the UK is unlawful, therefore one might argue that it is not fair to furnish them with services that facilitate their unlawful residence. Just as those in prison are denied certain rights, so too might it be argued that undocumented migrants, qua criminals, ought to be denied particular services. Yet even if one believes that a punitive approach is apposite, it is not

\footnotetext{
5 One can take this further: given that many workers across all sectors have migrated to the UK and contributed to the economy, surely their relatives ought also to be afforded access. One might also wish to factor in the contributions of those (descended from) workers within former British colonies who have contributed to the wealth that the NHS now draws upon. I return to this issue in the next section.
} 
clear that denying healthcare to a person is an appropriate or proportionate response. After all, even prisoners have access to healthcare. Nor has it been shown that barriers to healthcare reduce the number of undocumented migrants. A 2015 report conducted by Doctors of the World reports that migrants using their clinics waited an average 6.5 years before their first contact with a healthcare service, largely because of fears about arrest and deportation [13].

A related concern is that if everyone is permitted to use the NHS, then greater numbers of migrants will be drawn to the UK, threatening its sustainability. Yet the predicted effect, termed the "welfare magnet hypothesis" has no firm evidence base: migration decisions are not made on the basis of the generosity of welfare entitlements, and across Europe, migrants underuse welfare entitlements despite greater levels of deprivation [29]. In the UK, migrants underuse the health services to which they are entitled [74], despite having more demanding physical and mental health needs [49]. Accordingly, reducing entitlements is likely to limit the health of migrants, rather than their numbers.

Changing tack, one might argue that the notion of fairness being drawn upon here relates not to contributions, but simply to citizenship. One might see NHS care as a benefit of British citizenship, i.e. the UK government has a duty to cater for the (health) needs of UK citizens, regardless of their contributions. In turn, UK citizens accept the constraints and duties of citizenship, including (for most) the requirement that they contribute to the NHS. Yet this argument rests on a misrepresentation. NHS services are free to those who are ordinarily resident within the UK, which excludes British citizens who are resident abroad and includes non-citizens living in the UK long-term [54]. Residence within the jurisdiction is the critical criterion, not citizenship, which makes it difficult to justify excluding undocumented migrants. ${ }^{6}$ Even glossing this, another difficulty arises. Allowing members (whether citizens or residents) access to free NHS services, while excluding non-members, proves difficult to ground without circularity. As Cole points out, membership is defined through its associated benefits, which begs the question of how that membership is initially justified [14]. Any attempt to ground the difference via the claim that members have contributed to welfare, while non-members have not, is undermined by the fact that membership is also defined by its associated duties i.e. contribution. Non-contributors cannot contribute; non-contributors cannot access healthcare. Further, instead claiming that non-members must be instrumentally excluded in order to protect the rights of members is similarly circular: how does one justify refusing to meet the needs of one group to protect the needs of another, i.e. what is the moral basis for determining which people will count as "insiders" and "outsiders"?

Section two closed by noting that the justifiability of the new charging regime depends on the veracity of two claims: that restricting migrants' access to the NHS (a) saves money, and (b) makes the service fairer. The evidence and arguments provided within this section and the previous one cast doubt on both (a) and (b).

\footnotetext{
${ }^{6}$ Hundreds of thousands of whom have been living in the UK long enough to qualify for regularisation [30].
} 


\section{In Search of Fairness and Frugality}

Fairness and frugality are understandable ambitions within a publicly-funded health service. Scarce essential goods must be distributed with sensitivity to moral considerations. This section addresses the challenge of upholding these values while maintaining moral legitimacy with respect to migrants' relationship to the healthcare service.

So far, I have shown that charging migrants for their care is likely to cost more money than it saves and that there is no obvious notion of fairness which can consistently ground the exclusion of migrants from free NHS care. One could argue that, in the absence of any consistent moral or financial grounds for charging migrants, their NHS care should be free. This argument can be strengthened if positive grounds can also be given. Further, the conceptions of fairness adjudicated in the last section were primarily economic (i.e. utilitarian) in nature, since the government frames its decisions that way, yet even if it were the case that charging migrants was cost-effective, there would still be non-utilitarian moral arguments to consider. In this section I briefly consider some arguments in favour of free NHS care for all, regardless of nationality or immigration status.

One obvious way to conceive of fairness within a health service which is used and staffed by migrants, against the backdrop of a globalised world, is moral cosmopolitanism. Moral cosmopolitanism demands that moral consideration be oblivious to state borders; every person must be factored into moral calculations, regardless of nationality [9]. Applying this to the matter at hand, two moral statements can be generated: we must not deny healthcare to a person based on nationality; we must not deny NHS roles to healthcare workers based on nationality. Elsewhere, I have argued that the first of these principles is being violated in the NHS while the second is being upheld (even if not for these reasons) [66]. Accordingly, the NHS realises a partial moral cosmopolitanism in its interactions with migrants, or, less charitably but more accurately, the NHS inconsistently applies moral cosmopolitanism. Since it is not realistic or morally acceptable to restrict the freedom of movement of migrant healthcare workers, I recommend that a more consistent moral cosmopolitanism be attained by allowing all patients free access to the NHS, regardless of their nationality. In other words, the NHS is not currently fair, but could be made fairer by removing any restriction based on residence or nationality.

A similar conclusion can be reached via utilitarian considerations. One could argue that a publicly-funded health service has a duty to taxpayers to provide optimal value for money. Accordingly, it should minimise any non-essential costs. First, employing migrant workers within the NHS is currently the most economical way of running the service, ${ }^{7}$ since: the UK struggles to train and retain sufficient numbers of healthcare workers; the training costs of migrant workers has been met elsewhere; any staffing shortfall requires locum staff to be paid at higher rates. Second, the available evidence seems to indicate that the bureaucracy required to charge

\footnotetext{
7 This raises moral issues of its own, but I set those aside here in order to maintain the focus of this paper. See e.g. $[31,66]$.
} 
migrants for NHS treatment outweighs the costs that can be recovered. Third, if migrant patients are deterred from seeking care, larger costs may be incurred later as patients develop complications. Ensuring that the NHS is free for all seems to be the most frugal way of running the service, which is thereby the fairest use of taxpayers' contributions.

Two separate incidents involving migrant nurses from Kenya highlighted the absurdity of the current "partial cosmopolitanism." As visa-holders, they were required to pay the immigration health surcharge for themselves and their dependents for each year of their 5-year visas. For a family of four, this would currently amount to a payment of $£ 8000$. Unable to raise the required sum, one nurse sent two children back to Kenya [55], while another left two children behind in the care of relatives [44]. These nurses, who had trained and qualified in Kenya, either having sponsored themselves or having received state-sponsorship [40], had been employed to help address staff shortages within the UK's largely free healthcare system, yet were unable to access free healthcare for themselves and their families. It is hard to imagine a conception of fairness that this situation does not violate.

Another way of grounding the UK's responsibilities towards migrants is to consider the causal role that the UK has played in the production of the events (e.g. war, regime change, economic crisis) which have led to large numbers of migrants seeking new lives in Europe [8]. The top five nationalities of asylum-seekers and undocumented migrants to the UK are Iran, Pakistan, Iraq, Bangladesh, and Sudan [79]. All have been strongly affected by British imperialism, and have since been characterised by one or more of widespread poverty, repressive governance, or military intervention, which are predictable consequences of colonialism [10, 47, 81]. This causal connection can be used to argue that the UK has "reparative responsibilities" to make amends for past actions which still affect many people today [47], or "associative duties" to share the economic benefits gleaned through previous associative ties of colonialism [86]. One straightforward way to begin to meet these responsibilities would be to extend welfare rights, such as free healthcare, to migrants from affected regions. This analysis could be broadened to cover migrants from all Global South states by noting that current global financial institutions, designed and maintained by the interests of wealthy Global North nations, perpetuate Global South poverty [61]. Accordingly, welfare entitlements such as free NHS care could be extended to Global South migrants as a step towards realising international distributive justice [3].

Finally, there are important medical ethics concerns to consider. ${ }^{8}$ Under the new regime, patients are entitled to free primary care and emergency care, but are charged for any care resulting from a referral from either of these services. While much of the bureaucracy of charging for treatment is managed within dedicated finance departments, doctors must recommend chargeable treatments where they are medically indicated, and in the same breath inform patients of their chargeability, in order to provide optimal information with respect to treatment decisions. Yet this

\footnotetext{
${ }^{8}$ See e.g. $[8,67,87]$ for additional arguments from medical ethics.
} 
transforms the doctor-patient encounter so that financial considerations become a central, and often determinative, aspect of medical decision-making, and healthcare workers face substantial new moral burdens, plausibly leading to considerable moral distress $[2,23,67]$. Consider the difficulty of referring a patient for cancer treatment or maternity care and having the patient refuse the referral due to concerns about costs or immigration status [68]. While many other health systems have always operated on this basis, to introduce a two-tier system and its concomitant moral burdens into a system whose workers did not train with the expectation of that additional moral labour raises serious concerns. One could therefore argue that in order for medical professionals to meet their professional ethical duties, comprehensive free NHS care should be available to all. ${ }^{9}$

\section{Conclusion: Austerity and Xenophobia}

In this paper I have demonstrated that migrants' reduced access to NHS services does not achieve the fairness and frugality that are ostensibly sought, because it very likely costs more to administrate such a system that can be earned from it. Further, related anti-immigration policies endanger the supply of migrant labour upon which the NHS relies in order to provide care inexpensively. On the question of fairness, I have adjudicated various moral grounds for denying free healthcare to migrants, and have found that they lead to inconsistencies. Further, I have offered arguments in favour of extending free healthcare to migrants.

If charging "overseas visitors" for their care cannot reasonably be claimed to be impelled by fairness and frugality, what are the likely motivations? To answer this question, one must confront the fact that xenophobic attitudes in the UK are some of the strongest in Europe, and have been emboldened by the recent Brexit referendum, as well as being a major driver of its result [83]. Opposition to immigration is common across all regions, ages, and political allegiances, and is strongly determined by fears about threats to British culture and national identity, concerns about welfare use, and racial prejudice [4, 22]. In June 2016, just ahead of the referendum, $48 \%$ of those surveyed saw immigration or immigrants as the most important issue facing Britain, and the NHS as the second most important issue [37]. Not only is xenophobia widespread, but racism is a strong element, with the UK public preferring Western European and Australian immigration, followed by Eastern European, and then West Indian and Indian or Pakistani immigration-in other words, preferences for immigrants tracks racialisation, with white immigrants favoured [4].

Within political discourse, immigration and austerity have a complicated interdependent relationship. Even though austerity policies were ostensibly a response to a global financial downturn, in the UK they have tended to target particular groups, who are represented as making illegitimate, underhand claims on the nation's

\footnotetext{
9 This position can also be motivated via virtue ethics, in considering the virtues that underwrite the role of a medical professional [58].
} 
financial resources. This narrative is so compelling to many that immigration is liable to be blamed for the poverty and inequality caused by austerity measures [19]. Austerity is used as an excuse to implement further restrictions on immigration and on migrants' access to services alongside broader fiscal cuts, the ensuing scarcity is then often attributed to immigration, which seems to recommend further restrictions on immigration and migrants. A similar story can be told in relation to welfare claimants. In making and announcing targeted cuts, the government constructs and highlights the moral transgressions of these "undeserving" groups in such a way as to render them likely scapegoats for the negative effects of broader austerity measures. Burnett describes the two "folk-devils that have been elevated to the forefront of narratives of austerity: the migrant and the home-grown "scrounger'" [11]. This is an incisive summary of the government's strategy, according to which the withdrawal of resources from groups that were in any case "undeserving" furnishes its own moral legitimacy. A corollary of this interdependence is that austerity regimes are exacerbating racism [71], and there seems to be evidence for this across Europe [56].

The current political climate in the UK compels the government to prioritise decisions which demonstrate its hostility to migrants regardless of the economic costs. It is telling that the current charging regime does not appear to have been rigorously costed $[16,17,51,85]$. To fail to carefully cost a new policy in a time of austerity is unthinkable unless either the potential political reward outweighs any economic cost, or policy-makers have themselves been persuaded by folk wisdom about migrants being a drain on the economy. Either case has xenophobia at its root. Any politician or political party that attempts to explain the value of immigration, either morally or economically, is liable to be undercut by the realpolitik of a rival who has the advantage of a pre-existing discourse of fear and hatred. For those trading in xenophobia, the NHS is an astute choice. As one commentator put it: "the NHS is almost a religion in the UK; its "overstretching" — especially by foreignerspresented as a blasphemy" [28].

In October 2018, the Chancellor of the Exchequer Philip Hammond announced that the "era of austerity" was "finally coming to an end" but at the same time set out a budget for the year head which entails a $£ 1$ billion cut to health spending [80]. Meanwhile, the United Nations Special Rapporteur on extreme poverty and human rights has issued a damning condemnation of the effects of austerity on the most vulnerable [6], and has described the plight of asylum seekers and migrants in the UK in strong terms:

Destitution is built into the asylum system. Asylum seekers are banned from working and limited to a derisory level of support that guarantees they will live in poverty. The government promotes work as the solution to poverty, yet refuses to allow this particular group to work. [...] For those who have no recourse to public funds as a result of their immigration status, the situation can be particularly difficult [59].

The full extent of the concomitant health consequences is not yet known, but the government's failure to release reports of the effects of charging on migrants' health 
has led to concern amongst medical professional bodies, and accusations of suppression [12].

In summary, the xenophobia that has been constructed within the UK is more likely to cost the NHS in the long run, since excluding migrants produces substantial additional bureaucratic costs and costly medical complications, while the employment of much-needed migrant workers is obstructed. This is aside from the serious moral cost of failing to provide for the health needs of migrant patients. Readers may be reminded of another high price the UK is paying for currying political favour via the espousal and entrenchment of xenophobic discourses. As I write, the cost of leaving the EU as a result of the 2016 Brexit referendum stands at $£ 26$ billion per year even prior to the economic losses which will be incurred as a result of leaving the EU Customs Union trade bloc [72]. It is unsurprising that rousing xenophobia in a globalised world will incur economic (not to mention moral) costs, yet this is evidently considered to be worth the convenience of a credible political scapegoat in a nation in which racism has such robust currency [39].

Acknowledgements I am grateful to Angeliki Kerasidou and Patricia Kingori for hosting the symposium within which this article was conceived, and to Tamsin Hinton-Smith and Rebecca Webb for leading the "Space to Write" workshops within which it was written. I wish to thank Fionnuala Finnerty for many stimulating discussions on this topic.

Open Access This article is distributed under the terms of the Creative Commons Attribution 4.0 International License (http://creativecommons.org/licenses/by/4.0/), which permits unrestricted use, distribution, and reproduction in any medium, provided you give appropriate credit to the original author(s) and the source, provide a link to the Creative Commons license, and indicate if changes were made.

\section{References}

1. Abubakar, I., Aldridge, R. W., Devakumar, D., et al. (2018). The UCL-Lancet Commission on Migration and Health: the health of a world on the move. The Lancet, 392, 2606-2654.

2. Berlinger, N., \& Raghavan, R. (2013). The ethics of advocacy for undocumented patients. Hastings Center Report, 43, 14-17. https://doi.org/10.1002/hast.126.

3. Blake, M., \& Smith, P. T. (2013). International distributive justice.

4. Blinder, S. (2011). UK public opinion toward migration: Determinants of attitudes. Migration Observatory Briefing. Oxford: University of Oxford.

5. Bloomer, E., Allen, J., Donkin, A., et al. (2012). The impact of the economic downturn and policy changes on health inequalities in London. London: UCL Institute of Health Equity.

6. Booth, R. (2019). UN report compares Tory welfare policies to creation of workhouses. The Guardian. https://www.theguardian.com/politics/2019/may/22/un-report-compares-tory-welfare-reformsto-creation-of-workhouses. Accessed 22 May 2019.

7. Bozorgmehr, K., \& Razum, O. (2015). Effect of restricting access to health care on health expenditures among asylum-seekers and refugees: A quasi-experimental study in Germany, 1994-2013. PLoS ONE, 10, e0131483. https://doi.org/10.1371/journal.pone.0131483.

8. Brannan, S., Campbell, R., Davies, M., et al. (2016). The Mediterranean refugee crisis: Ethics, international law and migrant health. Journal of Medical Ethics, 42, 269-270. https://doi.org/10.1136/ medethics-2016-103444.

9. Brock, G. (2015). Global justice, cosmopolitan duties and duties to compatriots: The case of healthcare. Public Health Ethics, 8, 110-120.

10. Bruhn, M., \& Gallego, F. A. (2012). Good, bad, and ugly colonial activities: Do they matter for economic development? Review of Economics and Statistics, 94, 433-461. 
11. Burnett, J. (2017). Austerity and the production of hate. In V. Cooper \& D. Whyte (Eds.), The violence of austerity. London: Pluto Press.

12. Campbell, D. (2019). Ministers accused of cover-up over migrant health reports. The Guardian. https:/www.theguardian.com/uk-news/2019/apr/03/ministers-accused-of-cover-up-over-migranthealth-reports-nhs. Accessed 22 May 2019.

13. Chauvin, P., Simonnot, N., Vanbiervliet, F., et al. (2014). Access to healthcare for people facing multiple vulnerabilities in health in 26 cities across 11 countries. Report on the social and medical data gathered in 2014.

14. Cole, P. (2007). Human rights and the national interest: Migrants, healthcare and social justice. Journal of Medical Ethics, 33, 269-272. https://doi.org/10.1136/jme.2005.014829.

15. David Cameron: The age of austerity: Conservative Party Speeches. SayIt. https://conservativespeeches.sayit.mysociety.org/speech/601367. Accessed 3 December 2018.

16. Department of Health. Visitor and Migrant NHS Cost Recovery-Amending and Extending the Charging Regulations. Department of Health (2017). http://www.legislation.gov.uk/ukia/2017/121/ pdfs/ukia_20170121_en.pdf.

17. Department of Health. (2014). Visitor \& Migrant NHS Cost Recovery Programme-Implementation Plan 2014-2016.

18. Dertent, H. (2017) Department of Health. (2017). Making a fair contribution: Government response to the consultation on the extension of charging overseas visitors and migrants using the NHS in England. https://assets.publishing.service.gov.uk/government/uploads/system/uploads/attachment _data/file/590027/Cons_Response_cost_recovery.pdf.

19. Dorling, D. (2016). Brexit: the decision of a divided country. BMJ, 354, i3697. https://doi. org/10.1136/bmj.i3697.

20. Department of Health \& Social Care. (2018). Upfront charging operational framework to support identification and charging of overseas visitors. GOV.UK. https://www.gov.uk/government/ publications/overseas-nhs-visitors-framework-to-support-identification-and-upfront-charging/upfro nt-charging-operational-framework-to-support-identification-and-charging-of-overseas-visitors. Accessed 24 August 2018

21. Dustmann, C., \& Frattini, T. (2014). The fiscal effects of immigration to the UK. The Economic Journal, 124, F593-F643. https://doi.org/10.1111/ecoj.12181.

22. Dustmann, C., \& Preston, I. P. (2007). Racial and economic factors in attitudes to immigration. The BE Journal of Economic Analysis and Policy, 7, 507.

23. Fourie, C. (2015). Moral distress and moral conflict in clinical ethics. Bioethics, 29, 91-97. https:// doi.org/10.1111/bioe.12064.

24. Freedom of Information Office, Basingstoke and North Hampshire Hospital. Freedom of Information Request: Cost of Overseas Team. (2016). https://www.whatdotheyknow.com/request/309929/ response/764217/attach/2/LTE4\%20Completion\%20202\%202015.pdf?cookie_passthrough=1.

25. Freedom of Information Office, Basingstoke and North Hampshire Hospital. Freedom of Information Request: Charges Made in Accordance with Immigration Act. (2016). https://www.whatd otheyknow.com/request/310141/response/782681/attach/2/LTE4\%20Completion\%20019\%20201 6.pdf?cookie_passthrough=1.

26. General Medical Council. GMC says government must address visa issue. https://www.gmc-uk.org/ news/news-archive/gmc-says-government-must-address-visa-issue. Accessed 6 December 2018.

27. General Medical Council. The state of medical education and practice in the UK. https://www.gmcuk.org/about/what-we-do-and-why/data-and-research/the-state-of-medical-education-and-practicein-the-uk. Accessed 6 December 2018.

28. Gietel-Basten, S. (2016). Why Brexit? The toxic mix of immigration and austerity. Population and Development Review, 42, 673-680. https://doi.org/10.1111/padr.12007.

29. Giulietti, C. (2014). The welfare magnet hypothesis and the welfare take-up of migrants. IZA World of Labor.

30. Gordon, I., Scanlon, K., Travers, T., et al. (2009). Economic impact on the London and UK economy of an earned regularisation of irregular migrants to the UK. Greater London Authority.

31. Groenhout, R. (2015). The "brain drain" problem: Migrating medical professionals and global health care. IJFAB: International Journal of Feminist Approaches to Bioethics, 1, 6. https://doi. org/10.3138/ijfab.5.1.1.

32. Hanefeld, J., Horsfall, D., Lunt, N., et al. (2013). Medical tourism: A cost or benefit to the NHS? PLOS ONE. https://doi.org/10.1371/journal.pone.0070406. 
33. Hardin, R. (2013). The free rider problem. In: E. N. Zalta (Ed.), The Stanford encyclopedia of philosophy. Metaphysics Research Lab, Stanford University. https://plato.stanford.edu/archives/spr20 13/entries/free-rider/. Accessed 16 May 2019.

34. Health Tourism: What's the Cost? Full Fact. https://fullfact.org/health/health-tourism-whats-cost/. Accessed 30 August 2018.

35. Immigration Act 2014. http://www.legislation.gov.uk/ukpga/2014/22/introduction/enacted. Accessed 3 December 2018.

36. Information Requests from the Home Office to NHS Digital. GOV.UK. https://www.gov.uk/gover nment/publications/information-requests-from-the-home-office-to-nhs-digital. Accessed 3 December 2018 .

37. Ipsos MORI. Concern about immigration rises as EU vote approaches. Ipsos MORI. https://www. ipsos.com/ipsos-mori/en-uk/concern-about-immigration-rises-eu-vote-approaches. Accessed 28 January 2019.

38. Keith, L., \& Van Ginneken, E. (2015). Restricting access to the NHS for undocumented migrants is bad policy at high cost. BMJ. https://doi.org/10.1136/bmj.h3056.

39. Khalili, L. (2017). After Brexit: Reckoning with Britain's racism and xenophobia. Poem, 5, 253265. https://doi.org/10.1080/20519842.2017.1292758.

40. Kirigia, J. M., Gbary, A. R., Muthuri, L. K., et al. (2006). The cost of health professionals' brain drain in Kenya. BMC Health Services Research, 6, 89. https://doi.org/10.1186/1472-6963-6-89.

41. Kirkup, J. (2012). Theresa May interview: 'We're going to give illegal migrants a really hostile reception'. https://www.telegraph.co.uk/news/uknews/immigration/9291483/Theresa-May-inter view-Were-going-to-give-illegal-migrants-a-really-hostile-reception.html. Accessed 3 December 2018.

42. Lafond, S., \& Charlesworth, A. (2016). A perfect storm: An impossible climate for NHS providers' finances? The Health Foundation. https://www.health.org.uk/publications/a-perfect-storm-an-impos sible-climate-for-nhs-providers\%E2\%80\%99-finances. Accessed 18 December 2018.

43. Lee, G. (2018). FactCheck: How generous have the Conservatives been with the NHS? Channel 4 News. https://www.channel4.com/news/factcheck/factcheck-how-generous-have-the-conservativesbeen-with-the-nhs. Accessed 31 January 2019.

44. Lime, A. (2018). The UK health tax hurting foreign nurses. https://www.bbc.com/news/world-afric a-44397315. Accessed 7 December 2018.

45. Lords Hansard text for 03 July 2013 (pt 0001). https://publications.parliament.uk/pa/ld201314/ldhan srd/text/130703-wms0001.htm\#13070359000077. Accessed 16 May 2019.

46. Lydall, R. (2018). 8900 Checks on NHS 'health tourists' find just 50 liable to pay. Evening Standard. https://www.standard.co.uk/news/health/8900-checks-on-nhs-health-tourists-find-just-50-liabl e-to-pay-a3850121.html. Accessed 7 December 2018.

47. McKeown, M. (2011). Who bears responsibility for post-colonial poverty? Unpublished paper. In Princeton graduate political theory conference. Princeton, NJ.

48. Migrant Access to Health Services in the UK: Consultation. GOV.UK. https://www.gov.uk/gover nment/consultations/migrant-access-to-health-services-in-the-uk. Accessed 5 December 2018.

49. Mladovsky, P. (2007). Migrant health in the EU. EUROHEALTH-LONDON, 13, 9.

50. National Health Service-Hansard. (2017). https://hansard.parliament.uk/Commons/2017-02-06/ debates/1702061000009/NationalHealthService?highlight=overseas\%20visitors\%20nhs\%20\%22fai rness\%22\#contribution-C4537602-9879-4DD1-BE39-5FC46B3079A2. Accessed 18 January 2019.

51. National Audit Office. (2016). Recovering the cost of NHS treatment for overseas visitors.

52. NHS Improvement. Quarterly performance of the NHS provider sector: quarter 2 2018/19 I NHS Improvement. https://improvement.nhs.uk/resources/quarterly-performance-nhs-provider-secto r-quarter-2-201819/. Accessed 7 December 2018.

53. NHS Improvement. Agency caps one year on: Expenditure reduced by $£ 600 \mathrm{~m}$, but spending is still too high I NHS Improvement. https://improvement.nhs.uk/news-alerts/agency-caps-one-year-600msaved-nhs-spending-still-too-high/. Accessed 7 December 2018.

54. NHS. (2018). Planning your healthcare. nhs.uk. https://www.nhs.uk/using-the-nhs/healthcare-abroa d/moving-abroad/planning-your-healthcare/. Accessed 17 May 2019.

55. NHS nurse forced to send children home to Kenya because she couldn't afford Home Office health surcharge. The Independent. (2018). https://www.independent.co.uk/news/health/nurse-evalineomondi-nhs-children-kenya-home-office-health-surcharge-a8347801.html. Accessed 7 December 2018. 
56. Nielsen, N. EU austerity is feeding racism, report says. https://euobserver.com/social/116123. Accessed 28 January 2019.

57. Nuffield Trust, The Health Foundation, The King's Fund. The Autumn Budget: Joint statement on health and social care (2017). https:/www.kingsfund.org.uk/sites/default/files/2017-11/The\%20Aut umn $\% 20$ Budget $\% 20-\% 20$ joint $\% 20$ statement $\% 20$ on $\% 20$ health $\% 20$ and $\% 20$ social $\% 20$ care $\% 2$ C $\% 20$ Nov\%202017.pdf\#page $=6$.

58. Oakley, J., \& Cocking, D. (2001). Virtue ethics and professional roles. Cambridge: Cambridge University Press.

59. OHCHR I Statement on Visit to the United Kingdom, by Professor Philip Alston, United Nations Special Rapporteur on extreme poverty and human rights. https://www.ohchr.org/EN/NewsEvents/ Pages/DisplayNews.aspx?NewsID=23881\&LangID=E. Accessed 23 January 2019.

60. Poduval, S., Howard, N., Jones, L., et al. (2015). Experiences among undocumented migrants accessing primary care in the United Kingdom: A qualitative study. International Journal of Health Services, 45, 320-333. https://doi.org/10.1177/0020731414568511.

61. Pogge, T. (2010). The role of international law in reproducing massive poverty. In S. Besson \& J. Tasioulas (Eds.), The philosophy of international law. Oxford: Oxford University Press.

62. Points-Based Immigration System-Hansard. https://hansard.parliament.uk/Commons/2008-04-24/ debates/08042466000002/Points-BasedImmigrationSystem?highlight=points-based $\% 20$ trust $\% 20$ immigration\#contribution-08042466000703. Accessed 17 May 2019.

63. Press Association. (2014). David Cameron defends "moral mission" on welfare. The Guardian. https://www.theguardian.com/society/2014/feb/19/david-cameron-moral-mission-welfare-archb ishop-westminster. Accessed 24 January 2019.

64. Rafighi, E., Poduval, S., Legido-Quigley, H., et al. (2016). National health service principles as experienced by vulnerable London migrants in "Austerity Britain": A qualitative study of rights, entitlements, and civil-society advocacy. International Journal of Health Policy and Management, 5, 589-597. https://doi.org/10.15171/ijhpm.2016.50.

65. Reeves, A., Basu, S., McKee, M., et al. (2013). Austere or not? UK coalition government budgets and health inequalities. Journal of the Royal Society of Medicine, 106, 432-436. https://doi. org/10.1177/0141076813501101.

66. Shahvisi, A. (2018). Health worker migration and migrant healthcare: Seeking cosmopolitanism in the NHS. Bioethics, 32, 334-342. https://doi.org/10.1111/bioe.12432.

67. Shahvisi, A., \& Finnerty, F. (2019). Why it is unethical to charge for pregnancy care in the National Health Service. Journal of Medical Ethics. https://doi.org/10.1136/medethics-2018-105224.

68. Shahvisi, A., \& Finnerty, F. (2019). Charging migrant women for pregnancy care is a worrying sign of the times I Journal of Medical Ethics Blog. https://blogs.bmj.com/medical-ethics/2019/04/26/ charging-migrant-women-for-pregnancy-care-is-a-worrying-sign-of-the-times/. Accessed 22 May 2019.

69. Siddique, H. (2010). Agencies. Theresa May: immigration cap will not harm UK economy. The Guardian. https://www.theguardian.com/uk/2010/jun/28/theresa-may-immigration-cap-economy. Accessed 6 December 2018.

70. Simpson, J. M., Esmail, A., Kalra, V. S., et al. (2010). Writing migrants back into NHS history: Addressing a 'collective amnesia' and its policy implications. Journal of the Royal Society of Medicine, 103, 392-396. https://doi.org/10.1258/jrsm.2010.100222.

71. Spencer, D. Blame austerity-Not immigration-For taking Britain to "breaking point." The Conversation. http://theconversation.com/blame-austerity-not-immigration-for-taking-britain-to-break ing-point-61133. Accessed 28 January 2019.

72. Springford, J. (2018). The cost of Brexit to June 2018. Centre for European Reform. https://www. cer.eu/insights/cost-brexit-june-2018. Accessed 17 December 2018.

73. Stanley, L. (2016). Legitimacy gaps, taxpayer conflict, and the politics of austerity in the UK. The British Journal of Politics and International Relations, 18, 389-406.

74. Steventon, A., \& Bardsley, M. (2011). Use of secondary care in England by international immigrants. Journal of Health Services Research and Policy, 16, 90-94.

75. Taylor, M., Gidda, M., \& Syal, R. (2013). "Go home" ad campaign targeting illegal immigrants faces court challenge. The Guardian. https:/www.theguardian.com/uk-news/2013/jul/26/go-homead-campaign-court-challenge. Accessed 3 December 2018.

76. The King's Fund. What does the public think about the NHS? 2017. https://www.kingsfund.org.uk/ publications/what-does-public-think-about-nhs. Accessed 18 December 2018. 
77. The Open University. Tackling the nursing shortage http://www.open.ac.uk/business/apprentice ships/blog/tackling-the-nursing-shortage-May-2018. Accessed 7 December 2018.

78. The NHS. (2018). Visitors from the European Economic Area (EEA) or Switzerland. nhs.uk. https:// www.nhs.uk/using-the-nhs/nhs-services/visiting-or-moving-to-england/visitors-from-the-europeaneconomic-area-eea-or-switzerland/. Accessed 5 December 2018.

79. The Migration Observatory. (2019). Migration to the UK: Asylum and Refugees. Migration Observatory. https://migrationobservatory.ox.ac.uk/resources/briefings/migration-to-the-uk-asylum/. Accessed 20 May 2019.

80. The Health Foundation. (2018). Budget 2018: £1bn real terms cut to wider health budget. The Health Foundation. https://www.health.org.uk/news-and-comment/news/budget-2018-\%C2\%A31bn -real-terms-cut-to-wider-health-budget. Accessed 20 May 2019.

81. Tusalem, R. F. (2016). The colonial foundations of state fragility and failure. Polity, 48, 445-495.

82. Visitor and Migrant NHS Cost Recovery Programme-Hansard. https://hansard.parliament.uk/ Commons/2014-07-14/debates/14071410000012/VisitorAndMigrantNHSCostRecoveryProgramm e?highlight=overseas $\% 20$ visitors $\% 20$ nhs $\% 20 \% 22$ fairness $\% 22$ \#contribution- 14071410000040 . Accessed 18 January 2019.

83. Vlandas, T. (2016). Xenophobia Britannica? Anti-immigrant attitudes in the UK are among the strongest in Europe. LSE BREXIT. http://blogs.lse.ac.uk/brexit/2016/10/21/xenophobia-britannica -anti-immigrant-attitudes-in-the-uk-are-among-the-strongest-in-europe/. Accessed 15 December 2018.

84. Waldron, D., \& Ali, S. (2015). Tier 2 visa problems making NHS staffing crisis worse. Workpermit. com. http://workpermit.com/news/tier-2-visa-problems-making-nhs-staffing-crisis-worse-20150917. Accessed 6 December 2018.

85. Williams, M. (2017). Experts say new NHS charging policy is not fully costed. Channel 4 News. https://www.channel4.com/news/factcheck/experts-say-new-nhs-charging-policy-is-not-fully-costed. Accessed 11 December 2018.

86. Ypi, L., Goodin, R. E., \& Barry, C. (2009). Associative duties, global justice, and the colonies. Philosophy and Public Affairs, 37, 103-135.

87. Zaklaki, R. D. (2019). Access to health care for illegal migrants: Ethical implications of a new health policy in the UK. British Journal of General Practice, 69, 56-57.

Publisher's Note Springer Nature remains neutral with regard to jurisdictional claims in published maps and institutional affiliations. 